Article

\title{
An Efficient and Facile Methodology for Bromination of Pyrimidine and Purine Nucleosides with Sodium Monobromoisocyanurate (SMBI)
}

\author{
Jyotirmoy Maity * and Roger Stromberg * \\ Department of Biosciences and Nutrition, Karolinska Institute (KI), Novum, Huddinge SE-141 83, \\ Sweden
}

* Authors to whom correspondence should be addressed; E-Mails: Jyotirmoy.Maity@ki.se (J.M.); Roger.Stromberg@ki.se (R.S.); Tel.: +46-8-5248-1024 (R.S.); Fax: +46-8-5248-1034 (R.S.).

Received: 2 September 2013; in revised form: 2 October 2013 / Accepted: 9 October 2013 /

Published: 15 October 2013

\begin{abstract}
An efficient and facile strategy has been developed for bromination of nucleosides using sodium monobromoisocyanurate (SMBI). Our methodology demonstrates bromination at the C-5 position of pyrimidine nucleosides and the C-8 position of purine nucleosides. Unprotected and also several protected nucleosides were brominated in moderate to high yields following this procedure.
\end{abstract}

Keywords: bromination; sodium monobromoisocyanurate (SMBI); pyridine-based nucleosides; purine-based nucleosides; bromonucleosides

\section{Introduction}

Over the past decades, 5-halopyrimidine nucleosides have been found to be of interest for their antiviral [1-3] and antineoplastic [4,5] properties. 5-Bromo-2'-deoxyuridine has shown in vivo antiviral activity through its incorporation into the DNA of replicating cells as a structural analogue of thymidine [6]. Radiolabeled 5-bromo- and 5-iodo-pyrimidine nucleoside analogues have been tested for their potential in diagnostic oncology [7]. In search of new potential agents with superior biological activity, a variety of structural and functional moieties have been introduced into pyrimidine and purine nucleoside analogues by palladium assisted routes [8]. Halonucleosides have been used extensively as starting material for these reactions. 8-Bromopurine nucleosides have been used as key intermediates for synthesizing fluorescently labeled nucleosides, which have promising applications in 
the field of molecular biology $[9,10]$. In view of this relevance, development of efficient methodology for the synthesis of 5-bromopyrimidine and 8-bromopurine nucleosides is always of immense interest.

Direct halogenation of nucleosides has been found to be a proficient approach for the synthesis of 5-halopyrimidine, 6-halopurine [11-13] and 8-halopurine nucleosides [14]. Unprotected and protected nucleosides have been halogenated by direct reaction with halogens or halogenating agents. Bromination at C-5 of pyrimidine moieties was achieved by reaction of $\mathrm{Br}_{2} /$ water [15], $\mathrm{Br}_{2} / \mathrm{DMF}$ [16], $\mathrm{Br}_{2} / \mathrm{CCl}_{4}$ [17], $\mathrm{Br}_{2} / \mathrm{CCl}_{4}$ in solvent mixture of anhydrous acetic acid and pyridine [18], $N$-bromosuccinimide (NBS) in $\mathrm{DMF}$ [19], NBS/NaN 3 in DME [20], NBS in ionic liquids [21], $m$-chloroperbenzoic acid (MCPBA)/HBr in DMA or DMF [22], ceric ammonium nitrate $(\mathrm{CAN}) / \mathrm{LiBr}$ in $\mathrm{AcOH}$ or $\mathrm{MeCN}$ [23], $\mathrm{KBr} /$ potassium monoperoxysulfate under aqueous conditions [24]. Bromination of $\mathrm{C}-8$ of purine moieties has been attained by reaction of $\mathrm{Br}_{2}$ in glacial $\mathrm{AcOH} / \mathrm{NaOAc}$ [25], NBS in $\mathrm{DMF}$ [19], $\mathrm{Br}_{2}$ in $\mathrm{NaOAc}$ buffer/dioxane [10] and $\mathrm{Br}_{2}$ in $\mathrm{NaOAc}$ buffer [26,27]. A thorough study of the literature procedures for bromination of nucleosides shows that most of these methods have some disadvantages, such as highly acidic reaction condition, handling of toxic reagents, longer reaction time, complicated work up procedure and low yield of the products. Noticeably, very few of these methods are general for bromination of pyrimidine nucleosides as well as purine nucleosides.

In recent years, sodium monobromoisocyanurate (SMBI) has proven its capacity as an efficient brominating agent. It has been used in various solvents to brominate a range of aromatic moieties with both activating and deactivating substituents [28]. Bromination of azulene derivatives with SMBI was achieved in DCM and DCM/water [29]. Unprotected aromatic amino acids were also brominated with $\mathrm{SMBI}$ in aq. $\mathrm{H}_{2} \mathrm{SO}_{4}$ to produce mono-brominated products in good yield [30]. SMBI has also been found to act as a catalyst for the synthesis of aryl thiocyanates [31]. Following the literature on SMBI, we believed it to be an efficient brominating agent for nucleosides. In this report, we describe the ability of SMBI to brominate the C-5 of pyrimidine nucleosides and C-8 of purine nucleosides. Along with unprotected nucleosides of naturally occurring bases, we have also successfully brominated nucleosides with alkyl, silyl, dimethoxytrityl (DMTr)/monomethoxytrityl (MMTr) protection on the sugar moiety and/or acyl protection on the nucleobase. DMTr/ MMTr groups are among the most frequently used protective groups in nucleoside chemistry. Due to their high sensitivity towards acidic reaction conditions, there is no literature procedure available for bromination of DMTr/MMTr protected nucleosides. Here we report for the first time in literature bromination of DMTr/MMTr protected nucleosides.

\section{Results and Discussion}

Initially, we tried to brominate the C-5 position of uridine (1) and screened various reaction conditions (Scheme 1, Table 1). Treatment of 1 with SMBI (1.05 equiv.) in a solvent mixture of $10 \% \mathrm{H}_{2} \mathrm{O}-\mathrm{CH}_{3} \mathrm{CN}$ in presence of $\mathrm{NaN}_{3}$ (4.0 equiv.) at room temperature produced 5-bromouridine (2) $[20,21,23,32]$ in $94 \%$ yield within 30 minutes. Next, we tried another reaction with 1 , where we added 2.0 equiv. of $\mathrm{NaN}_{3}$ keeping other conditions unaltered. Bromo nucleoside 2 was obtained in $88 \%$ yield in $2 \mathrm{~h}$ by this reaction. However, when 1 was treated with SMBI (1.15 equiv.) in $10 \% \mathrm{H}_{2} \mathrm{O}-\mathrm{CH}_{3} \mathrm{CN}$ in the absence of $\mathrm{NaN}_{3}$ at room temperature, the bromination reaction was slow and took a longer time (18 h) to afford 2 in only $40 \%$ yield. 
Scheme 1. Bromination of uridine and derivatives thereof.

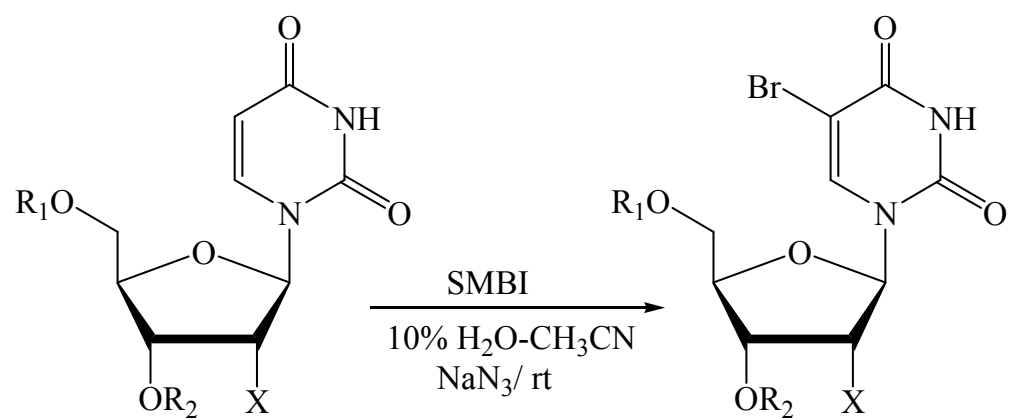

1, $2 \mathrm{R}_{1}=\mathrm{H} ; \mathrm{R}_{2}=\mathrm{H}, \mathrm{X}=\mathrm{OH}$

3, $4 \quad \mathrm{R}_{1}=\mathrm{H} ; \mathrm{R}_{2}=\mathrm{H}, \mathrm{X}=\mathrm{H}$

5, $6 \quad \mathrm{R}_{1}=\mathrm{H} ; \mathrm{R}_{2}=\mathrm{H}, \mathrm{X}=\mathrm{OCH}_{3}$

7, $8 \quad \mathrm{R}_{1}=\mathrm{DMTr} ; \mathrm{R}_{2}=\mathrm{H}, \mathrm{X}=\mathrm{OH}$

9, $10 \mathrm{R}_{1}, \mathrm{R}_{2}=$ TIPDS, $\mathrm{X}=\mathrm{OH}$

11,12 $R_{1}=$ TBDPS; $R_{2}=H, X=O H$

Table 1. Screening for appropriate bromination condition of uridine and bromination of uridine derivatives.

\begin{tabular}{ccccccccc}
\hline Entry & Substrate & Product & $\begin{array}{c}\text { SMBI } \\
\text { (eq.) }\end{array}$ & $\begin{array}{c}\mathbf{N a N}_{3} \\
\text { (eq.) }\end{array}$ & Solvent & $\begin{array}{c}\text { Reaction } \\
\text { time (h) }\end{array}$ & $\begin{array}{c}\text { Yield (\%) } \\
\text { (NMR/TLC) }\end{array}$ & $\begin{array}{c}\text { Isolated } \\
\text { yield (\%) }\end{array}$ \\
\hline 1 & $\mathbf{1}$ & $\mathbf{2}$ & 1.05 & 4.0 & $10 \% \mathrm{H}_{2} \mathrm{O}-\mathrm{CH}_{3} \mathrm{CN}$ & 0.5 & $94^{a}$ & $79^{b}$ \\
2 & $\mathbf{1}$ & $\mathbf{2}$ & 1.05 & 2.0 & $10 \% \mathrm{H}_{2} \mathrm{O}-\mathrm{CH}_{3} \mathrm{CN}$ & 1.5 & $88^{a}$ & - \\
3 & $\mathbf{1}$ & $\mathbf{2}$ & 1.15 & 0 & $10 \% \mathrm{H}_{2} \mathrm{O}-\mathrm{CH}_{3} \mathrm{CN}$ & 18.0 & $40^{c}$ & - \\
4 & $\mathbf{1}$ & $\mathbf{2}$ & 1.15 & 0 & $20 \% \mathrm{H}_{2} \mathrm{O}-\mathrm{DMF}$ & 18.0 & $15^{c}$ & - \\
5 & $\mathbf{3}$ & $\mathbf{4}$ & 1.05 & 4.0 & $10 \% \mathrm{H}_{2} \mathrm{O}-\mathrm{CH}_{3} \mathrm{CN}$ & 1.2 & $90^{a}$ & $86^{d}$ \\
6 & $\mathbf{5}$ & $\mathbf{6}$ & 1.15 & 4.0 & $10 \% \mathrm{H}_{2} \mathrm{O}-\mathrm{CH}_{3} \mathrm{CN}$ & 1.5 & - & $93^{d}$ \\
7 & $\mathbf{7}$ & $\mathbf{8}$ & 1.1 & 4.0 & $10 \% \mathrm{H}_{2} \mathrm{O}-\mathrm{CH}_{3} \mathrm{CN}$ & 1.0 & $86^{a}$ & $81^{d}$ \\
8 & $\mathbf{9}$ & $\mathbf{1 0}$ & 1.1 & 4.0 & $10 \% \mathrm{H}_{2} \mathrm{O}-\mathrm{CH}_{3} \mathrm{CN}$ & 1.5 & $94^{a}$ & $91^{d}$ \\
9 & $\mathbf{1 1}$ & $\mathbf{1 2}$ & 1.1 & 4.0 & $10 \% \mathrm{H}_{2} \mathrm{O}-\mathrm{CH}_{3} \mathrm{CN}$ & 1.2 & - & $92^{d}$ \\
\hline \multicolumn{7}{c}{ Yield calculated by ${ }^{1} \mathrm{H}-\mathrm{NMR}$ spectroscopy of the crude reaction mixture. ${ }^{b}$ Isolated yield after crystallization. } \\
\multicolumn{7}{c}{ Yield judged by TLC. ${ }^{d}$ Isolated yield after purification by column chromatography. }
\end{tabular}

We also investigated bromination of 1 in $20 \% \mathrm{H}_{2} \mathrm{O}-\mathrm{DMF}$ without addition of $\mathrm{NaN}_{3}$. Even after a prolonged reaction time $(18 \mathrm{~h})$ bromo-nucleoside 2 was only obtained in low yield. Analysis of these reaction conditions applied for uridine (entry 1/entry 2 /entry 3/entry 4, Table 1 ) verifies the crucial role of $\mathrm{NaN}_{3}$ in the halogenation reactions (bromination reactions in our case) at the C-5 position of the pyrimidine nucleosides. The azido group plays the role of an excellent leaving group from the C-6 position of the 5-halo-6-azido-5,6-dihydro intermediates to restore the 5,6-olefinic bond [20]. The bromination reaction conditions optimized for uridine (1) were next successfully employed for other uridine derivatives. Bromination of 2'-deoxyuridine (3) was carried out with SMBI (1.05 equiv.) and $\mathrm{NaN}_{3}$ (4.0 equiv.) in $10 \% \mathrm{H}_{2} \mathrm{O}-\mathrm{CH}_{3} \mathrm{CN}$ which produced 5-bromo-2'-deoxyuridine (4) $[20,21,23]$ in 90\% yield (Table 1). 2'-O-Methyluridine (5) was treated under the same reaction conditions, followed by addition of 0.1 equiv. of SMBI after $1 \mathrm{~h}$. The reaction was stopped after $1.5 \mathrm{~h}$ and purification of the product by column chromatography afforded 5-bromo-2'-O-methyluridine (6) in 93\% yield. 
Reaction of 5'-O-dimethoxytrityluridine (7) with 1.1 equiv. of SMBI in $10 \% \mathrm{H}_{2} \mathrm{O}-\mathrm{CH}_{3} \mathrm{CN}$ in the presence of $\mathrm{NaN}_{3}$ (4.0 equiv.) produced bromo nucleoside 8 [33] in 86\% yield. Similar treatment of silyl protected nucleosides 3',5'-O-tetraisopropyldisilyl-uridine (9) and 5'-O-tert-butyldiphenylsilyluridine (11) with 1.1 equivalent of SMBI afforded the corresponding bromonucleosides 10 [34] and 12 in $94 \%$ and $92 \%$ yields, respectively.

We then applied our methodology for the bromination of cytidine (13) (Scheme 2). Nucleoside 13 was treated with 1.05 equiv. of SMBI in presence of $\mathrm{NaN}_{3}$ (4.0 equiv.) in $10 \% \mathrm{H}_{2} \mathrm{O}-\mathrm{CH}_{3} \mathrm{CN}$ at rt. The progress of the reaction was followed by TLC. Additional amounts of SMBI ( 0.2 equiv. each time) were added into the reaction mixture after $1 \mathrm{~h}$ and $2 \mathrm{~h}$. This reaction produced 5-bromocytidine (14) in $83 \%$ yield after $3 \mathrm{~h}$ (Table 2). In another reaction, 13 was dissolved in 20\% $\mathrm{H}_{2} \mathrm{O}-\mathrm{DMF}$ and treated with 1.2 equiv. of SMBI, followed by further additions of the reagent ( 0.3 equiv. each time) after $3 \mathrm{~h}$ and $6 \mathrm{~h}$ stirring at rt. The reaction was stirred for $20 \mathrm{~h}$, followed by the work up, which produced the brominated nucleoside 14 in $73 \%$ yield. The reaction time and yield for bromination of $\mathbf{1 3}$ (entry 1/entry 2, Table 2) were compared, which indicated the first conditions to be more efficient.

Scheme 2. Bromination of cytidine and derivatives thereof.

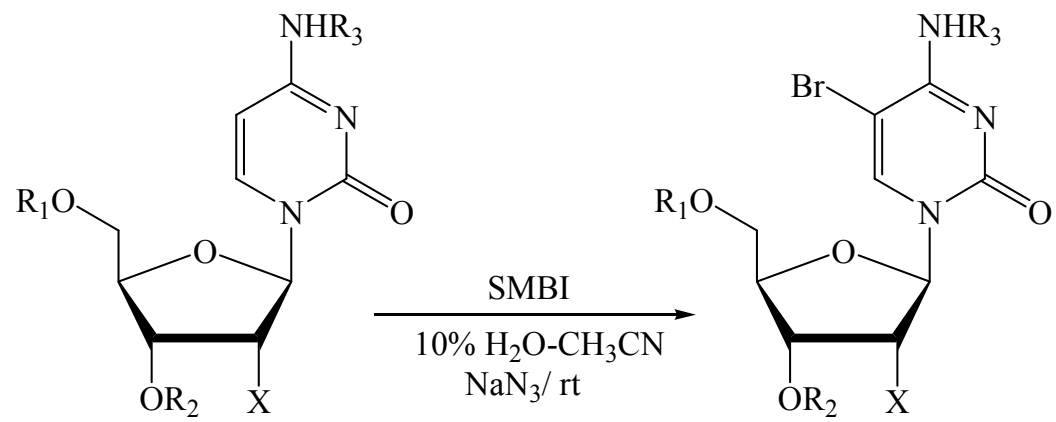

13, $14 \mathrm{R}_{1}=\mathrm{H} ; \mathrm{R}_{2}=\mathrm{H}, \mathrm{X}=\mathrm{OH}, \mathrm{R}_{3}=\mathrm{H}$

15, $16 \mathrm{R}_{1}=\mathrm{H} ; \mathrm{R}_{2}=\mathrm{H}, \mathrm{X}=\mathrm{H}, \mathrm{R}_{3}=\mathrm{H}$

17, $18 \mathrm{R}_{1}=\mathrm{H} ; \mathrm{R}_{2}=\mathrm{H}, \mathrm{X}=\mathrm{OCH}_{3}, \mathrm{R}_{3}=\mathrm{H}$

19, $20 \mathrm{R}_{1}=\mathrm{MMTr} ; \mathrm{R}_{2}=\mathrm{H}, \mathrm{X}=\mathrm{OH}, \mathrm{R}_{3}=\mathrm{COCH}_{2} \mathrm{CH}_{3}$

Table 2. Comparison of suitable bromination condition for cytidine and bromination of cytidine derivatives.

\begin{tabular}{ccccccccc}
\hline Entry & Substrate & Product & $\begin{array}{c}\text { SMBI } \\
\text { (eq.) }\end{array}$ & $\begin{array}{c}\mathbf{N a N}_{\mathbf{3}} \\
(\mathbf{e q .})\end{array}$ & Solvent & $\begin{array}{c}\text { Reaction } \\
\text { time (h) }\end{array}$ & $\begin{array}{c}\text { Yield (\%) } \\
\text { (NMR) }\end{array}$ & $\begin{array}{c}\text { Isolated } \\
\text { yield (\%) }\end{array}$ \\
\hline 1 & $\mathbf{1 3}$ & $\mathbf{1 4}$ & 1.45 & 4.0 & $10 \% \mathrm{H}_{2} \mathrm{O}-\mathrm{CH}_{3} \mathrm{CN}$ & 3.0 & $83^{a}$ & $69^{b}$ \\
2 & $\mathbf{1 3}$ & $\mathbf{1 4}$ & 1.8 & 0 & $20 \% \mathrm{H}_{2} \mathrm{O}-\mathrm{DMF}$ & 20.0 & $73^{a}$ & - \\
3 & $\mathbf{1 5}$ & $\mathbf{1 6}$ & 1.6 & 4.0 & $10 \% \mathrm{H}_{2} \mathrm{O}-\mathrm{CH}_{3} \mathrm{CN}$ & 3.5 & $73^{a}$ & $66^{c}$ \\
4 & $\mathbf{1 7}$ & $\mathbf{1 8}$ & 1.25 & 4.0 & $10 \% \mathrm{H}_{2} \mathrm{O}-\mathrm{CH}_{3} \mathrm{CN}$ & 2.0 & - & $78^{c}$ \\
5 & $\mathbf{1 9}$ & $\mathbf{2 0}$ & 1.25 & 4.0 & $10 \% \mathrm{H}_{2} \mathrm{O}-\mathrm{CH}_{3} \mathrm{CN}$ & 2.5 & - & $59^{c}$ \\
\hline
\end{tabular}

${ }^{a}$ Yield calculated by ${ }^{1} \mathrm{H}$-NMR spectroscopy of the crude reaction mixture. ${ }^{b}$ Isolated yield after crystallization. ${ }^{c}$ Isolated yield after purification by column chromatography.

We then performed a reaction of nucleoside 15 with 1.2 equiv. of SMBI in $10 \% \mathrm{H}_{2} \mathrm{O}-\mathrm{CH}_{3} \mathrm{CN}$ and in the presence of $\mathrm{NaN}_{3}$. Following the progress of the reaction on TLC, an excess amount of SMBI ( 0.2 equiv. each time) was added after $1.5 \mathrm{~h}$ and $3 \mathrm{~h}$. 5 -Bromo-dC, 16, was obtained in $73 \%$ yield after 
$3.5 \mathrm{~h}$ stirring at rt. 2'-O-Methylcytidine (17) was treated with 1.25 equiv. of SMBI (entry 4, Table 3) which produced nucleoside $\mathbf{1 8}$ in 78\% yield after $2 \mathrm{~h}$. When $N^{4}$-propanoyl-5'-O-dimethoxytritylcytidine (19) [35] was treated with 1.25 equiv. of SMBI, 5-bromo- $N^{4}$-propanoyl-5'-O-dimethoxytritylcytidine (20) was obtained in $59 \%$ yield in $2.5 \mathrm{~h}$. (entry 5 , Table 2 ).

Table 3. Bromination conditions for purine nucleosides.

\begin{tabular}{cccccccc}
\hline Entry & Substrate & Product & $\begin{array}{c}\text { SMBI } \\
\text { (eq.) }\end{array}$ & Solvent & $\begin{array}{c}\text { Reaction } \\
\text { time (h) }\end{array}$ & $\begin{array}{c}\text { Yield (\%) } \\
\text { (NMR/TLC) }\end{array}$ & $\begin{array}{c}\text { Isolated } \\
\text { yield (\%) }\end{array}$ \\
\hline 1 & $\mathbf{2 1}$ & $\mathbf{2 2}$ & 1.4 & $20 \% \mathrm{H}_{2} \mathrm{O}-\mathrm{DMF}$ & 2.5 & $89^{a}$ & $73^{b}$ \\
2 & $\mathbf{2 3}$ & $\mathbf{2 4}$ & 1.3 & $20 \% \mathrm{H}_{2} \mathrm{O}-\mathrm{DMF}$ & 2.0 & $93^{a}$ & $88^{d}$ \\
3 & $\mathbf{2 5}$ & $\mathbf{2 6}$ & 1.45 & $20 \% \mathrm{H}_{2} \mathrm{O}-\mathrm{DMF}$ & 2.0 & $78^{a}$ & $71^{d}$ \\
4 & $\mathbf{2 7}$ & $\mathbf{2 8}$ & 1.2 & $20 \% \mathrm{H}_{2} \mathrm{O}-\mathrm{DMF}$ & 4.0 & $4^{c}$ & - \\
5 & $\mathbf{2 9}$ & $\mathbf{3 0}$ & 1.5 & $20 \% \mathrm{H}_{2} \mathrm{O}-\mathrm{DMF}$ & 4.0 & $15^{c}$ & - \\
6 & $\mathbf{3 1}$ & $\mathbf{3 2}$ & 1.5 & $20 \% \mathrm{H}_{2} \mathrm{O}-\mathrm{DMF}$ & 4.0 & $62^{a}$ & $57^{d}$ \\
7 & $\mathbf{3 3}$ & $\mathbf{3 4}$ & 1.25 & $20 \% \mathrm{H}_{2} \mathrm{O}-\mathrm{DMF}$ & 2.0 & - & $6^{d}$ \\
\hline
\end{tabular}

${ }^{a}$ Yield calculated by ${ }^{1} \mathrm{H}-\mathrm{NMR}$ spectroscopy of the crude reaction mixture. ${ }^{b}$ Isolated yield after crystallization. ${ }^{c}$ Yield judged by TLC. ${ }^{d}$ Isolated yield after purification by column chromatography.

Unlike the pyrimidine nucleosides, purine nucleosides were not completely soluble in $10 \%$ $\mathrm{H}_{2} \mathrm{O}-\mathrm{CH}_{3} \mathrm{CN}$. This observation led us to carry out the reactions in $20 \% \mathrm{H}_{2} \mathrm{O}-\mathrm{DMF}$. Adenosine (21) was treated with SMBI (1.1 equiv.) in 20\% $\mathrm{H}_{2} \mathrm{O}-\mathrm{DMF}$ at $\mathrm{rt}$ and the reaction was monitored by TLC (Scheme 3$)$. Additional amounts of the reagent were added ( 0.2 equiv. after $1 \mathrm{~h}$ and 0.1 equiv. after 2 $\mathrm{h}$ ) to drive the reaction towards completion. Reaction was stopped after $2.5 \mathrm{~h}$ to afford the brominated nucleoside 22 [26,32,36] in 89\% yield (entry 1, Table 3).

Scheme 3. Bromination of adenosine and derivatives thereof.

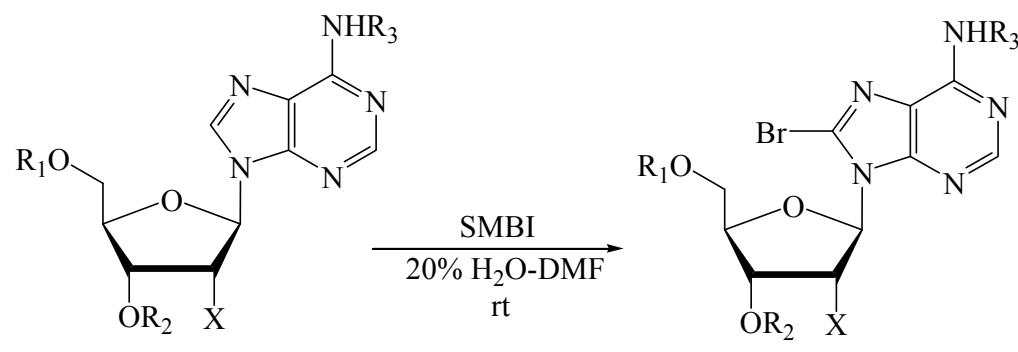

21, $22 \mathrm{R}_{1}=\mathrm{H} ; \mathrm{R}_{2}=\mathrm{H}, \mathrm{X}=\mathrm{OH}, \mathrm{R}_{3}=\mathrm{H}$

23, $24 \mathrm{R}_{1}=\mathrm{H} ; \mathrm{R}_{2}=\mathrm{H}, \mathrm{X}=\mathrm{H}, \mathrm{R}_{3}=\mathrm{H}$

25, $26 \mathrm{R}_{1}=\mathrm{H} ; \mathrm{R}_{2}=\mathrm{H}, \mathrm{X}=\mathrm{OCH}_{3}, \mathrm{R}_{3}=\mathrm{H}$

27, $28 \mathrm{R}_{1}=\mathrm{MMTr} ; \mathrm{R}_{3}=\mathrm{H}, \mathrm{X}=\mathrm{OH}, \mathrm{R}_{3}=\mathrm{COCH}_{2} \mathrm{CH}_{2} \mathrm{CH}_{3}$

Deoxyadenosine, 23, was stirred with 1.25 equiv. of SMBI for $1 \mathrm{~h}$ followed by addition of 0.5 equiv of the reagent. Reaction was stopped after stirring for another $1 \mathrm{~h}$ when compound 24 [10] was obtained in $93 \%$ yield. Similarly, 2'-O-Methyladenosine (25) was treated with SMBI (1.25 equiv.), and the reaction mixture was stirred for $1 \mathrm{~h}$, followed by addition of 0.2 equiv. of the reagent. Reaction was worked up after $2 \mathrm{~h}$, and the bromonucleoside 26 [27] was obtained in 78\% yield. However, the 5'-Oand base protected nucleoside 27 [35] was found to be unsuitable for bromination under these reaction conditions. We could trace the product by ESI-TOF mass spectroscopy, but it was difficult to isolate from the reaction mixture as most of the starting material remained unreacted. 
Next, we extended the application of the SMBI reagent for guanine-based nucleosides. Guanosine (29) was treated with SMBI (1.25 equiv.) in 20\% $\mathrm{H}_{2} \mathrm{O}-\mathrm{DMF}$ at $\mathrm{rt}$, followed by addition of another lot of SMBI ( 0.25 equiv.) after $2 \mathrm{~h}$ (Scheme 4$)$. Reaction was stopped after $4 \mathrm{~h}$ to produce 8-bromo-guanosine (30) [37], albeit in low yield (entry 5, Table 3).

Scheme 4. Bromination of guanosine and derivatives thereof.

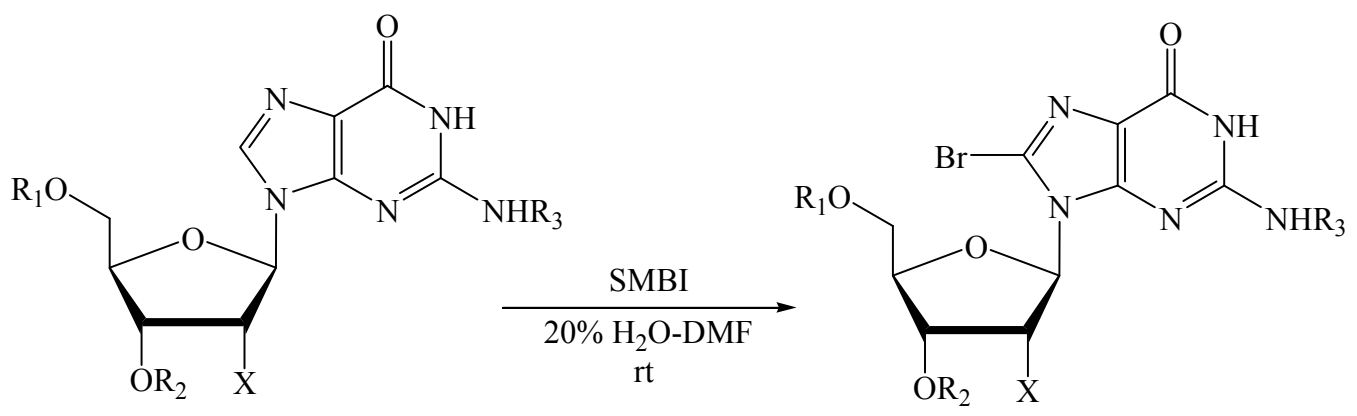

$$
\begin{aligned}
& \text { 29, } 30 R_{1}=H ; R_{2}=H, X=O H, R_{3}=H \\
& \text { 31, 32 } R_{1}=H ; R_{2}=H, X=H, R_{3}=H \\
& \text { 33, 34 } R_{1}=M M T r ; R_{2}=H, X=O H, R_{3}=C_{C O C H} O P h
\end{aligned}
$$

Similar treatment of deoxyguanosine, 31, with SMBI (starting the reaction with 1.25 equiv. of reagent and then addition of 0.25 equiv. of the reagent after $2 \mathrm{~h}$ stirring) produced $62 \%$ of bromo nucleoside 32 [37] in $4 \mathrm{~h}$. We did not get a very high yield for bromination of 29, so we explored these reaction conditions for a protected guanosine derivative. $N^{2}$-Phenyloxyacetyl-5'-O-monomethoxytritylguanosine (33) [35] was treated with 1.1 equiv. of SMBI and stirred at rt. After $1.5 \mathrm{~h}$, a supplementary amount ( 0.15 equiv.) of the reagent was added to drive forward the reaction. Bromonucleoside 34 was obtained from the reaction in $96 \%$ yield after $2 \mathrm{~h}$.

\section{Experimental}

\subsection{General}

All solvents were of commercial analytical grade and reagents were of commercial reagent grade and used without further purification. Anhydrous reactions were carried out under nitrogen atmosphere. ${ }^{1} \mathrm{H}-\mathrm{NMR}(400 \mathrm{MHz})$ and ${ }^{13} \mathrm{C}-\mathrm{NMR}(100 \mathrm{MHz})$ spectra were recorded in $\mathrm{D}_{2} \mathrm{O}$, DMSO- $d_{6}$, $\mathrm{CD}_{3} \mathrm{OD}$ or $\mathrm{CDCl}_{3}$ on a Bruker DRX 400. Chemical shifts are reported in ppm relative to tetramethylsilane or the deuterated solvent as internal standard for ${ }^{1} \mathrm{H}$ and ${ }^{13} \mathrm{C}-\mathrm{NMR}$. Coupling constants ( $J$ values) are given in Hz. Structural assignments are based on DEPT-135 and COSY experiments. HRMS-ESI was recorded on a Micromass LCT in negative ion mode. TLC was run on analytical TLC plates (silica gel $60 \mathrm{~F}_{254}$ ), purchased from Merck (Stockholm, Sweden). Spots were visualized by UV light.

\subsection{Typical Procedure for the Bromination of Pyrimidine Nucleosides and Their Derivatives}

2'-O-Methyluridine $(\mathbf{5}, 0.103 \mathrm{~g}, 0.4 \mathrm{mmol})$ was dissolved in aqueous acetonitrile solution $\left(\mathrm{H}_{2} \mathrm{O}: \mathrm{CH}_{3} \mathrm{CN}\right.$ 1:9, $\left.5 \mathrm{~mL}\right)$ under stirring. $\mathrm{NaN}_{3}(0.104 \mathrm{~g}, 1.6 \mathrm{mmol})$ was added, followed by addition of 
SMBI $(0.101 \mathrm{~g}, 0.44 \mathrm{mmol})$ at r.t. and the mixture was stirred. Progress of the reaction was followed by TLC. On completion of the reaction after $1.5 \mathrm{~h}$, the reaction mixture was filtered, evaporated to dryness under reduced pressure and coevaporated with acetonitrile $(2 \times 2 \mathrm{~mL})$. The crude reaction mixture was purified by column chromatography $(4 \%-6 \% \mathrm{MeOH}$ in $\mathrm{DCM}, \mathrm{v} / \mathrm{v})$ to afford bromo nucleoside $6(0.117 \mathrm{~g}, 93 \%)$ in pure form as a white solid.

5-Bromo-2'-O-methyluridine (6). M.p. Turns brown above $200{ }^{\circ} \mathrm{C} ; R_{f}=0.42(20 \%$ methanol in dichloromethane); ${ }^{1} \mathrm{H}-\mathrm{NMR}$ (DMSO- $\left.d_{6}\right): \delta=3.39\left(\mathrm{~s}, 3 \mathrm{H}, \mathrm{OCH}_{3}\right), 3.57-3.60\left(\mathrm{~m}, 1 \mathrm{H}, \mathrm{C}-5^{\prime} \mathrm{H}_{\mathrm{a}}\right.$ ), 3.69-3.73 $\left(\mathrm{m}, 1 \mathrm{H}, \mathrm{C}-5^{\prime} \mathrm{H}_{\mathrm{b}}\right), 3.81$ (t, $\left.J=4.4 \mathrm{~Hz}, 1 \mathrm{H}, \mathrm{C}-2^{\prime} \mathrm{H}\right), 3.86-3.87\left(\mathrm{~m}, 1 \mathrm{H}, \mathrm{C}-4{ }^{\prime} \mathrm{H}\right), 4.12$ (q, $J=5.6 \mathrm{~Hz}, 1 \mathrm{H}$, C-3'H), $5.12\left(\mathrm{~d}, J=6.4 \mathrm{~Hz}, 1 \mathrm{H}, \mathrm{C}-3^{\prime} \mathrm{OH}\right), 5.32\left(\mathrm{t}, J=4.4 \mathrm{~Hz}, 1 \mathrm{H}, \mathrm{C}-5^{\prime} \mathrm{OH}\right), 5.80(\mathrm{~d}, J=3.6 \mathrm{~Hz}, 1 \mathrm{H}$, $\mathrm{C}-1$ 'H), $8.53(\mathrm{~s}, 1 \mathrm{H}, \mathrm{C}-6 \mathrm{H}), 11.82(\mathrm{~s}, 1 \mathrm{H}, \mathrm{NH}) .{ }^{13} \mathrm{C}-\mathrm{NMR}\left(\mathrm{DMSO}-d_{6}\right): \delta=57.5\left(\mathrm{OCH}_{3}\right), 59.5\left(\mathrm{C}-5^{\prime}\right)$, 67.6 (C-3'), 82.9 (C-2'), 84.7 (C-4'), 86.6 (C-1'), 95.6 (C-5), 140.0 (C-6), 149.6 (C-2), 159.0 (C-4). HRMS-ESI $(\mathrm{m} / \mathrm{z})$ : calcd. for $\mathrm{C}_{10} \mathrm{H}_{12} \mathrm{BrN}_{2} \mathrm{O}_{6}[\mathrm{M}-\mathrm{H}]^{-}, 334.9884$; found 334.9881 .

5-Bromo-5'-O-tert-butyldiphenylsilyluridine (12). White solid (0.103 g, 92\%), M.p. Turns black above

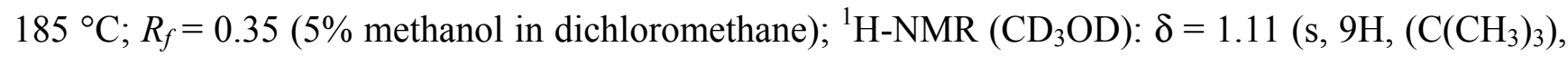
$3.84\left(\mathrm{dd}, J=11.6,3.2 \mathrm{~Hz}, 1 \mathrm{H}, \mathrm{C}-5^{\prime} \mathrm{H}_{\mathrm{a}}\right), 3.98\left(\mathrm{dd}, J=11.6,2.4 \mathrm{~Hz}, 1 \mathrm{H}, \mathrm{C}-5{ }^{\prime} \mathrm{H}_{\mathrm{b}}\right), 4.07-4.09$ (m, $1 \mathrm{H}$, C-4'H), 4.23-4.28 (m, 2H, C-2'H and C-3'H), 6.02 (d, $\left.J=5.6 \mathrm{~Hz}, 1 \mathrm{H}, \mathrm{C}-1{ }^{\prime} \mathrm{H}\right), 7.40-7.48(\mathrm{~m}, 6 \mathrm{H}$, C-3"H, C-4"H, C-5"H, C-3"'H, C-4'"H and C-5"'H), 7.72 (d, J = 7.2 Hz, 4H, C-2"H, C-6"H, C-2"'H and $\mathrm{C}-6$ '"H), 7.97 (s, $\left.1 \mathrm{H}, \mathrm{C}-6 \mathrm{H}) .{ }^{13} \mathrm{C}-\mathrm{NMR}\left(\mathrm{CD}_{3} \mathrm{OD}\right): \delta=20.2\left(\mathrm{C}\left(\mathrm{CH}_{3}\right)_{3}\right), 27.7\left(\mathrm{C} \mathrm{CH}_{3}\right)_{3}\right), 65.1\left(\mathrm{C}-5^{\prime}\right)$, 71.7 (C-2'), 76.1 (C-3'), 86.6 (C-4'), 90.2 (C-1'), 99.3 (C-5), 129.0 (C-3", C-5", C-3"' and C-5"'), 131.1 , 131.2 (C-4" and C-4"'), 133.8 , 134.1 (C-1" and C-1"'), 136.7 , 136.8 (C-2", C-6", C-2"' and C-6"'), 140.0 (C-6), 156.8 (C-2), 167.4 (C-4). HRMS-ESI ( $m / z)$ : calcd. for $\mathrm{C}_{25} \mathrm{H}_{28} \mathrm{BrN}_{2} \mathrm{O}_{6}[\mathrm{M}-\mathrm{H}]^{-}, 559.0905$; found 559.0927 .

5-Bromo-2'-O-methylcytidine (18). White solid (0.052 g, 78\%), M.p. $86-89^{\circ} \mathrm{C} ; R_{f}=0.36(2.5 \%$ methanol in dichloromethane); ${ }^{1} \mathrm{H}-\mathrm{NMR}\left(\mathrm{D}_{2} \mathrm{O}\right): \delta=3.49\left(\mathrm{~s}, 3 \mathrm{H}, \mathrm{OCH}_{3}\right), 3.77(\mathrm{dd}, J=9.0,3.6 \mathrm{~Hz}, 1 \mathrm{H}$, C-5' $\left.\mathrm{H}_{\mathrm{a}}\right), 3.88-3.91\left(\mathrm{~m}, 1.6 \mathrm{H}, \mathrm{C}-5^{\prime} \mathrm{H}_{\mathrm{b}(1)}\right.$ and $\left.\mathrm{C}-2^{\prime} \mathrm{H}\right), 3.94\left(\mathrm{~d}, J=2.4 \mathrm{~Hz}, 0.4 \mathrm{H}, \mathrm{C}-5^{\prime} \mathrm{H}_{\mathrm{b}(2)}\right), 4.01-4.04(\mathrm{~m}$, 1H, C-4'H), 4.22 (dd, $\left.J=7.2,5.2 \mathrm{~Hz}, 1 \mathrm{H}, \mathrm{C}-3{ }^{\prime} \mathrm{H}\right), 5.85$ (d, $\left.J=2.8 \mathrm{~Hz}, 1 \mathrm{H}, \mathrm{C}-1^{\prime} \mathrm{H}\right), 8.27$ (s, 1H, C-6H). ${ }^{13} \mathrm{C}-\mathrm{NMR}\left(\mathrm{D}_{2} \mathrm{O}\right): \delta=58.7\left(\mathrm{OCH}_{3}\right), 60.1\left(\mathrm{C}-5^{\prime}\right), 68.0\left(\mathrm{C}-3^{\prime}\right), 83.7\left(\mathrm{C}-2^{\prime}\right), 84.1\left(\mathrm{C}-4^{\prime}\right), 88.9\left(\mathrm{C}-1^{\prime}\right), 89.2$ (C-5), 142.5 (C-6), 156.5 (C-2), 163.3 (C-4). HRMS-ESI $(\mathrm{m} / \mathrm{z})$ : calcd. for $\mathrm{C}_{10} \mathrm{H}_{13} \mathrm{BrN}_{3} \mathrm{O}_{5}[\mathrm{M}-\mathrm{H}]^{-}$, 334.0044; found 334.0049.

5-Bromo-5'-O-monomethoxytrityl- $N^{4}$-propanoyl-2'-deoxycytidine (20). White solid (0.037 g, 59\%), M.p. $96-101{ }^{\circ} \mathrm{C} ; R_{f}=0.59$ (25\% methanol in dichloromethane); ${ }^{1} \mathrm{H}-\mathrm{NMR}\left(\mathrm{CDCl}_{3}\right): \delta=1.12(\mathrm{t}, J=7.2 \mathrm{~Hz}$, $\left.3 \mathrm{H}, \mathrm{COCH}_{2} \mathrm{CH}_{3}\right), 2.18-2.27\left(\mathrm{~m}, 1 \mathrm{H}, \mathrm{C}-2^{\prime} \mathrm{H}_{\mathrm{a}}\right), 2.43$ (br s, $\left.1 \mathrm{H}, \mathrm{C}-3{ }^{\prime} \mathrm{OH}\right), 2.68-2.71\left(\mathrm{~m}, 1 \mathrm{H}, \mathrm{C}-2^{\prime} \mathrm{H}_{\mathrm{b}}\right)$, 3.03-3.08 (m, 2H, $\left.\mathrm{COCH}_{2} \mathrm{CH}_{3}\right), 3.32\left(\mathrm{dd}, J=10.6,3.2 \mathrm{~Hz}, 1 \mathrm{H}, \mathrm{C}-5 \mathrm{H}_{\mathrm{a}}\right), 3.36(\mathrm{dd}, J=10.6,3.2 \mathrm{~Hz}$, $\left.1 \mathrm{H}, \mathrm{C}-5^{\prime} \mathrm{H}_{\mathrm{b}}\right), 3.73$ (s, 3H, OCH$)_{3}, 4.09-4.10$ (m, 1H, C-4'H), 4.49 (brs, 1H, C-3'H), 6.19 (t, J=6.4 Hz, 1H, C-1'H), 6.77 (d, $J=9.2 \mathrm{~Hz}, 2 \mathrm{H}, \mathrm{C}-3 " \mathrm{H}$ and C-5"H), 7.15-7.24 (m, 8H, C-2"H, C-6"H, C-3"'H, C-4"'H, C-5"'H, C-3"''H, C-4'"'H and C-5"''H), 7.33 (d, $J=7.6$ Hz, 4H, C-2'"H, C-6"'H, C-2'"'H and C-6"'"H), 7.78 (s, 1H, NHCO), $8.25(\mathrm{~s}, 1 \mathrm{H}, \mathrm{C}-6 \mathrm{H}) .{ }^{13} \mathrm{C}-\mathrm{NMR}\left(\mathrm{CDCl}_{3}\right): \delta=8.5\left(\mathrm{COCH}_{2} \mathrm{CH}_{3}\right), 32.0$ $\left(\mathrm{COCH}_{2} \mathrm{CH}_{3}\right), 42.4\left(\mathrm{C}-2^{\prime}\right), 55.4\left(\mathrm{OCH}_{3}\right), 63.4\left(\mathrm{C}-5^{\prime}\right), 72.2\left(\mathrm{C}-3^{\prime}\right), 87.0\left(\mathrm{C}-4^{\prime}\right), 87.5\left(\mathrm{OC}(\mathrm{Ar})_{3}\right), 87.8$ (C-1'), 88.2 (C-5), 113.5 (C-3" and C-5"), 127.4 (C-4'" and C-4'"'), 128.4 (C-2", C-6", C-3"', C-5"', 
C-3"'" and C-5"'"), 130.5 (C-2'", C-6"', C-2'"' and C-6"'"), 135.0 (C-1"), 143.5 (C-1"'), 143.9 (C-1"'), 144.0 (C-6), 153.5 (C-2), 157.2 (C-4"), 159.0 (C-4), 175.7 ( $\left.\mathrm{NHCOCH}_{2}\right)$. HRMS-ESI (m/z): calcd. for $\mathrm{C}_{32} \mathrm{H}_{31} \mathrm{BrN}_{3} \mathrm{O}_{6}[\mathrm{M}-\mathrm{H}]^{-}, 632.1402$; found 632.1411 .

\subsection{Typical Procedure for Bromination of Purine Nucleosides and Their Derivatives}

5'-O-Monomethoxytrityl- $N^{2}$-phenoxyacetylguanosine $(33,0.138 \mathrm{~g}, 0.2 \mathrm{mmol})$ was dissolved in aqueous DMF solution ( $\mathrm{H}_{2} \mathrm{O}: \mathrm{DMF}$ 1:4, $5 \mathrm{~mL}$ ) under stirring. SMBI (1.1 equiv., $0.051 \mathrm{~g}, 0.22 \mathrm{mmol}$ ) was added at r.t. and the mixture stirred. Progress of the reaction was followed by TLC. An additional amount of the reagent $(0.15$ equiv., $0.007 \mathrm{~g})$ was added into the reaction mixture after $1.5 \mathrm{~h}$. On completion of the reaction by $2 \mathrm{~h}$, the reaction mixture was filtered, evaporated to dryness under reduced pressure and coevaporated with water $(2 \times 2 \mathrm{~mL})$. The crude reaction mixture was purified by column chromatography (4\%-5\% MeOH in DCM, v/v) to afford nucleoside $34(0.148 \mathrm{~g}, 96 \%)$ in pure form as a white solid.

8-Bromo-5'-O-monomethoxytrityl- $N^{2}$-phenoxyacetylguanosine (34). M.p. $136-139{ }^{\circ} \mathrm{C} ; R_{f}=0.60(10 \%$ methanol in dichloromethane); ${ }^{1} \mathrm{H}-\mathrm{NMR}\left(\mathrm{CD}_{3} \mathrm{OD}\right): \delta=3.18\left(\mathrm{~d}, J=2.4 \mathrm{~Hz}, 0.5 \mathrm{H}, \mathrm{C}-5 \mathrm{H}_{\mathrm{a}}\right), 3.33(\mathrm{dd}$, $\left.J=10.0,6.4 \mathrm{~Hz}, 1 \mathrm{H}, \mathrm{C}-5{ }^{\prime} \mathrm{H}_{\mathrm{b}}\right), 3.59$ (s, 3H, OCH 3$), 4.04-4.09\left(\mathrm{~m}, 1 \mathrm{H}, \mathrm{C}-4{ }^{\prime} \mathrm{H}\right), 4.44$ (t, $J=5.6 \mathrm{~Hz}, 1 \mathrm{H}$, $\left.\mathrm{C}-3{ }^{\prime} \mathrm{H}\right), 4.58\left(\mathrm{~d}, J=15.2 \mathrm{~Hz}, 1 \mathrm{H}, \mathrm{COCH}_{2(\mathrm{a})} \mathrm{O}\right), 4.64\left(\mathrm{~d}, J=15.2 \mathrm{~Hz}, 1 \mathrm{H}, \mathrm{COCH}_{2(\mathrm{~b})} \mathrm{O}\right), 5.14(\mathrm{t}, J=4.8 \mathrm{~Hz}$, 1H, C-2'H), 5.91 (d, $J=4.4 \mathrm{~Hz}, 1 \mathrm{H}, \mathrm{C}-1$ 'H), 6.58 (d, $J=8.8 \mathrm{~Hz}, 2 \mathrm{H}, \mathrm{C}-3$ '"H and C-5'"H), 6.86-6.91 (m, 3H, C-2"H, C-4"H and C-6"H), 7.01-7.06 (m, 6H, C-3"''H, C-4'"'H, C-5'"'H, C-3"'"'H, C-4"''H and C-5"'"'H), 7.10 (d, $J=8.8 \mathrm{~Hz}, 2 \mathrm{H}, \mathrm{C}-2$ "'H and C-6"'H), 7.18 (t, $J=8.0 \mathrm{~Hz}, 2 \mathrm{H}, \mathrm{C}-3$ "H and C-5"H), 7.23-7.25 (m, 4H, C-2"'"H, C-6"'"H, C-2"'"'H and C-6"'"H). ${ }^{13} \mathrm{C}-\mathrm{NMR}\left(\mathrm{CD}_{3} \mathrm{OD}\right): \delta=55.7\left(\mathrm{OCH}_{3}\right), 65.6$ (C-5'), $68.3\left(\mathrm{COCH}_{2} \mathrm{O}\right), 72.0\left(\mathrm{C}^{2} 2^{\prime}\right), 72.8\left(\mathrm{C}-3^{\prime}\right), 85.7$ (C-4'), $87.6\left(\mathrm{OC}(\mathrm{Ar})_{3}\right), 92.9\left(\mathrm{C}-1^{\prime}\right), 113.9\left(\mathrm{C}-3^{\prime \prime \prime}\right.$ and C-5"'), 116.1 (C-2" and C-6"), 122.9 (C-5), 123.3 (C-4"), 127.4 (C-8), 127.9, 128.0, 129.6, 129.7, 130.8, 131.6 (C-2", C-3", C-5", C-6", C-2"', C-6"', C-2"'", C-3"'", C-4"'", C-5"'", C-6"'", C-2"'", C-3"'"', C-4"'", C-5"'"' and C-6"'"'), 136.6 (C-1"'), 145.8, 146.0 (C-1"'" and C-1"'"'), 148.3 (C-2), 151.1 (C-4), 156.3 (C-6), 159.0 (C-4"'), 160.1 (C-1"), $172.5\left(\mathrm{NHCOCH}_{2}\right)$. HRMS-ESI $(\mathrm{m} / \mathrm{z})$ : calcd. for $\mathrm{C}_{38} \mathrm{H}_{33} \mathrm{BrN}_{5} \mathrm{O}_{8}[\mathrm{M}-\mathrm{H}]^{-}$, 766.1518 ; found 766.1553 .

\section{Conclusions}

In summary, we report here the development of an efficient and facile methodology for the bromination of nucleosides. We have applied this process successfully for both purine and pyrimidine nucleosides. Our process presents an efficient methodology of bromination for ribonucleosides, 2'-deoxynucleosides, silyl protected and DMTr/MMTr protected nucleosides. We believe this methodology may be applied for the bromination of a wide range of nucleoside derivatives.

\section{Supplementary Materials}

Supplementary materials can be accessed at: http:/www.mdpi.com/1420-3049/18/10/12740/s1. 


\section{Acknowledgments}

We gratefully acknowledge financial support from the Swedish Research Council.

\section{Conflicts of Interest}

The authors declare no conflict of interest.

\section{References}

1. Van Aershot, A.; Everaert, D.; Balzarini, J.; Augustyns, K.; Jie, L.; Janssen, G.; Peeters, O.; Blaton, N.; DeRanter, C.; DeClercq, E.; Herdewijn, P. Synthesis and anti-HIV evaluation of 2',3'-dideoxyribo-5-chloropyrimidine analogues: Reduced toxicity of 5-chlorinated 2',3'-dideoxynucleoside. J. Med. Chem. 1990, 33, 1833-1839.

2. Fox, L.; Dorbersen, M.J.; Greer, S. Incorporation of 5-substituted analogs of deoxycytidine into DNA of herpes simplex virus-infected or -transformed cells without deamination to the thymidine analog. Antimicrob. Agents Chemother. 1983, 23, 465-476.

3. Harki, D.A.; Graci, J.D.; Galarraga, J.E.; Chain, W.J. Synthesis and antiviral activity of 5-substituted cytidine analogues: Identification of a potent inhibitor of viral RNA-dependent RNA polymerases. J. Med. Chem. 2006, 49, 6166-6169.

4. Perigaud, C.; Gosselin, G.; Imbach, J.L. Nucleoside analogues as chemotherapeutic agents: A review. Nucleosides Nucleotides 1992, 11, 903-945.

5. Clercq, E.; Balzarini, J.; Torrence, P.F.; Mertes, M.P.; Schmidt, C.L.; Shugar, D.; Barr, P.J.; Jones, A.S.; Verhelst, G.; Walker, R.T. Thymidylate synthetase as target enzyme for the inhibitory activity of 5-substituted 2'-deoxyuridines on mouse leukemia L1210 cell growth. Mol. Pharmacol. 1981, 19, 321-330.

6. Szybalski, W. X-ray sensitization by halopyrimidines. Cancer Chemother. Rep. 1974, 58, 539-557.

7. Mercer, J.R.; Xu, L.H.; Knaus, E.E.; Wiebe, L.I. Synthesis and tumor uptake of $5-{ }^{82} \mathrm{Br}-$ and 5- ${ }^{131}$ I-labeled 5-halo-1-(2-fluoro-2-deoxy- $\beta$-D-ribofuranosyl)uracils. J. Med. Chem. 1989, 32, 1289-1294.

8. Agrofoglio, L.A.; Gillaizeau, I.; Saito, Y. Palladium-assisted routes to nucleosides. Chem. Rev. 2003, 103, 1875-1916.

9. Amann, N.; Wagenknecht, H.-A. Preparation of pyrenyl-modified nucleosides via Suzuki-Miyaura cross-coupling reactions. Synlett 2002, 5, 687-691.

10. Clima, L.; Bannwarth, W. Building-block approach for the straightforward incorporation of a new FRET (Fluorescence-Resonance-Energy Transfer) system into synthetic DNA. Helv. Chim. Acta 2008, 91, 165-175.

11. Veliz, E.A.; Beal, P.A. 6-Bromopurine nucleosides as reagents for nucleoside analogue synthesis. J. Org. Chem. 2001, 66, 8592-8598.

12. De Napoli, L.; Messere, A.; Montesarchio, D.; Piccialli, G.; Varra, M. 6-Chloroxanthosine, a useful intermediate for the efficient syntheses of $\left[6{ }^{-15} \mathrm{~N}\right]$-isoguanosine, isoinosine and other purine nucleoside analogues. Nucleosides Nucleotides 1997, 16, 183-191. 
13. De Napoli, L.; Messere, A.; Montesarchio, D.; Piccialli, G.; Santacroce, C.; Varra, M. Reaction of 3',5'-di-O-acetyl-2'-deoxyinosine with the chlorinating agent $\mathrm{PPh}_{3}-\mathrm{CCl}_{4}$ : Synthesis of the 6-chloroderivative and of a new base linked dimer, useful intermediate to ${ }^{15} \mathrm{~N}$-1-labelled 2'-deoxxyinosine. J. Chem. Soc. Perkin Trans. 1, 1994, 1994, 923-925.

14. Ueda, T. Synthesis and Reaction of Pyrimidine Nucleosides. In Chemistry of Nucleosides and Nucleotides; Townsend, L.B., Ed.; Plenum Press: New York, NY, USA, 1988; Volume 1, pp. 1-95.

15. Fukuhara, T.K.; Visser, D.W. Pyrimidine nucleoside antagonisty. J. Biol. Chem. 1951, 190, 95-101.

16. Duval, J.; Ebel, J.P. Halogenation of nucleic acids: Action of bromine on bases and nucleosides in dimethylformamide medium. Bull. Soc. Chim. Biol. 1964, 46, 1059-1071.

17. Fukuhara, T.K.; Visser, D.W. Cytidine derivatives. J. Am. Chem. Soc. 1955, 77, 2393-2395.

18. Frisch, D.M.; Visser, D.W. 5-Bromodeoxycytidine and 5-chlorodeoxycytidine. J. Am. Chem. Soc. 1959, 81, 1756-1758.

19. Srivastava, P.C.; Nagpal, K.L. Bromination of nucleosides. Experientia 1970, 26, 220.

20. Kumar, R.; Wiebe, L.I.; Eknaus, E. A mild and efficient methodology for the synthesis of 5-halogeno uracil nucleosides that occurs via a 5-halogeno-6-azido-5,6-dihydro intermediate. Can. J. Chem. 1994, 72, 2005-2010.

21. Kumar, V.; Yap, J.; Muroyama, A.; Malhotra, S. Highly efficient method for C-5 halogenation of pyrimidine-based nucleosides in ionic liquid. Synthesis 2009, 23, 3957-3962.

22. Ryu, E.K.; MacCoss, M. New Procedure for the chlorination of pyrimidine and purine nucleosides. J. Org. Chem. 1981, 46, 2819-2923.

23. Asakura, J.; Robins, M.J. Cerium (IV) mediated halogenation at C-5 of uracil derivatives. J. Org. Chem. 1990, 55, 4928-4933.

24. Ross, S.A.; Burrows, C.J. Bromination of pyrimidines using bromide and monoperoxysulfate: A competition study between cytidine, uridine and thymidine. Tetrahedron Lett. 1997, 38, 2805-2808.

25. Holmes, R.E.; Robins, R.K. Purine nucleosides. VII. Direct bromination of adenosine, deoxyadenosine, guanosine, and related purine nucleosides. J. Am. Chem. Soc. 1964, 86, 1242-1245.

26. Ghanty, U.; Fostvedt, E.; Valenzuela, R.; Beal, P.A.; Burrows, C.J. Promiscuous 8-alkoxyadenosine in the guide strand of an SiRNA: Modulation of silencing efficacy and off-pathway protein binding. J. Am. Chem. Soc. 2012, 134, 17643-17652.

27. Ohkubo, A.; Nishino, Y.; Yokouchi, A.; Ito, Y.; Noma, Y.; Kakishima, Y.; Masaki, Y.; Tsunoda, H.; Seio, K.; Sekine, M. Stable triplex formation using the strong stacking effect of consecutive thionucleoside moieties. Chem. Commun. 2011, 47, 12556-12558.

28. Okada, Y.; Yokozawa, M.; Akiba, M.; Oishi, K.; O-kawa, K.; Akeboshi, T.; Kawamura, Y.; Inokuma, S.; Nakamura, Y.; Nishimura, J. Bromination by means of sodium monobromoisocyanurate (SMBI). Org. Biomol. Chem 2003, 1, 2506-2511.

29. Sumida, T.; Kikuchi, S.; Imafuku, K. Bromination of azulene derivatives with sodium monobromoisocyanurate. Synthetic Commun. 2004, 34, 4273-4284.

30. Yokoyama, Y.; Yamaguchi, T.; Sato, M.; Kobayashi, E.; Murakami, Y.; Okuno, H. Chemistry of unprotected amino acids in aqueous solution: Direct bromination of aromatic amino acids with bromoisocyanuric acid sodium salt under strong acidic condition. Chem. Pharm. Bull. 2006, 54, $1715-1719$. 
31. Kumar, J.A.; Srinivasan, N.; Shanmugham, C. Sodium monobromoisocyanurate: A new catalyst for direct synthesis of aryl thiocyanates. Int. J. Chem. 2011, 3, 95-98.

32. Ebrahimi, M.; Rossi, P.; Rogers, C.; Harbison, G.S. Dependence of ${ }^{13} \mathrm{C}$-NMR chemical shifts on conformations of RNA nucleosides and nucleotides. J. Magn. Reson. 2001, 150, 1-9.

33. Shah, K.; Wu, H.; Rana, T.M. Synthesis of uridine phosphoramidite analogues: Reagents for site-specific incorporation of photoreactive sites into RNA sequence. Bioconjug. Chem. 1994, 5, 508-512.

34. Matsuda, A.; Takenuki, K.; Tanaka, M.; Sasaki, T.; Ueda, T. Nucleosides and Nucleotides. 97. Synthesis of new broad spectrum antineoplastic nucleosides, 2'-deoxy-2'-methylidenecytidine (DMDC) and its derivatives. J. Med. Chem. 1991, 34, 812-819.

35. Westman, E.; Stawinski, J.; Stromberg, R. RNA synthesis using H-Phosphonates. Synchronizing 2'-OH and N-protection. Collect. Czech. Chem. Commun. 1993, 58, 236-237.

36. Mamos, P.; Van Aerschot, A.A.; Weyns, N.J.; Herdewijn, P.A. Straightforward C-8 alkylation of adenosine analogues with tetraalkyltin reagents. Tetrahedron Lett. 1992, 33, 2413-2416.

37. Wood, S.G.; Upadhya, K.G.; Dalley, N.K.; McKernan, P.A.; Canonico, P.G.; Robins, R.K.; Revankar, G.R. 8-Substituted guanosine and 2'-deoxyguanosine derivatives as potential inducers of the differentiation of friend erythroleukemia cells. J. Med. Chem. 1985, 28, 1194-1198.

Sample Availability: Samples of the compounds 2, 4, 6, 8, 10, 12, 14, 16, 18, 20, 22, 24, 26, 32 and 34 are available from the authors.

(C) 2013 by the authors; licensee MDPI, Basel, Switzerland. This article is an open access article distributed under the terms and conditions of the Creative Commons Attribution license (http://creativecommons.org/licenses/by/3.0/). 